\title{
Back pain and physical activity: Students of the Medical University of Lublin
}

\author{
Marta Lis-Sochocka*, Patrycja Chylinska-Wrzos, Ewelina Wawryk-Gawda, \\ Kamila Bulak, Barbara JODLOWSKA-JEDrYCH
}

Chair and Department of Histology and Embryology with Experimental Cytology Unit, Medical University of Lublin, Poland

\section{ARTICLE INFO \\ Received 08 October 2015 \\ Accepted 03 December 2015}

\section{Keywords:}

back pain,

health behaviors,

physical activity,

young people.

\begin{abstract}
At the present time, back pain and posture problems affect a growing number of young people. This is probably due to a changing lifestyle which has led to less physical activity. The aims of our study were to evaluate the prevalence of pain associated with the spine, as well as to ascertain the relationship of these symptoms with the degree of physical activity among a group of students of the Medical University of Lublin. The research group consisted of 301 students (201 women and 100 men) aged between 19 and 27 years. The survey was performed at the turn of the year 2014/2015.

Based on an anonymous questionnaires, we found that treatment and advice obtained at the faulty posture and/or orthopedic clinic benefited slightly more than $32 \%$ of all respondents. In this group, about $20 \%$ were women, while among men, it was a little over $12 \%$. Physical therapy to treat back problems was also entered into by about $29 \%$ of the respondents, while $5 \%$ of students undertook such treatment very frequently. What is more, $89 \%$ of all respondents stated they regularly attend physical education classes. Moreover, more than $81 \%$ of all students surveyed practiced some sport, in this group - about $51 \%$ of the respondents stating so were women, and a little over $29 \%$ were men. Although medical students are a group of people with high health issue awareness, they are not deprived of problems related to the musculoskeletal system.
\end{abstract}

\section{INTRODUCTION}

Back pain is a common clinical symptom among patients in contemporary populations [20]. Today, young people are especially exposed to a sedentary lifestyle. This is due to their spending a lot of time at the desk, and due to the computerization of the learning process at home $[9,20]$. This situation can perpetuate bad posture habits and can lead to physical abnormalities, spinal deformities and back pain in later life, still, back pain occurs even in childhood [19]. However, research has shown that a high degree of appropriate recreational physical activity in childhood minimises back pain symptoms at an early age [20]. In this respect, preventive exercises are promoted in schools during physical education classes [13]. Unfortunately, literature sources report that the level of physical activity of children is generally low. Indeed, only half of all public schools in the United States of America provide children with 20 minutes of exercise per day [20]. The WHO recommends that children

\footnotetext{
* Corresponding author

e-mail: martasochocka@wp.pl
}

and adolescents aged 5-17 years should practice moderate to intense physical activity for 60 minutes daily. For the population aged 18-64, the WHO recommends 150 minutes of moderate weekly physical activity [1]. In Poland, the number of mandatory hours of physical education in primary schools is 4 hours a week, while in secondary schools, this figure is 3 hours a week [24]. Thus, as evidenced by these figures, the majority of Polish adolescents do not reach the recommended level of physical activity [1]. The risk for deformation of the physiological curvatures of the spine comes about due to a number of factors, including obesity, poor paraspinal muscle tension, and incorrect posture when exercising [13]. The most important factor seems to be, however, the practicing of a sitting lifestyle, because the spine is then more tensioned than it is when lying down or standing [9]. The spending of many hours at a desk without proper adjustment of seat height and without correct profiling of the backrest, weakens the muscles, joints and tendons over time. This effect can deepen the lumbar and cervical lordosis or kyphosis. Equally dangerous is to reinforce bad 
habits among young people in adopting poor posture while reading or watching $\mathrm{TV}$, hence, disrupting the normal development of the paraspinal muscles [9]. In regard to this, it is recognized that a sitting posture with crossed legs and the twisting of the upper body to one side while reading, may induce a three dimensional deformity of the spine. Of note, spinal deformities are more often observed in women because of the weaker muscles of the upper body [8]. This is also due to the unilateral carrying of shoulder bags instead of backpacks [8]. Any abnormality in the shape of the spine is the source of pain as a result of pressure being applied on the spinal nerves extending from the spinal cord. Most often, neck pain, shoulder and lower back pain is the diagnosed effect [7]. In one study, it was revealed that chronic pain, that which lasts longer than three months, afflicts one patient in five respondents in Europe [11]. If the pain is chronic, there is a need to correct posture, hence, physical therapy becomes necessary. Exercises, including that which is intended for correction, should be cyclic, repetitive and adapted to the patient's posture disorders [11]. Based on current research, posture and silhouette are closely correlated with the adopted lifestyle. While the biggest changes in the spine come about due to growth and human physical development, the silhouette is subjected to continuous life-long remodelling [10]. Of further note, the level of awareness among young people about the impact of physical activity on the status of the spine and posture is improved now in the era of greater access to information and better medical care, yet this problem persists.

\section{GOAL}

The aim of our study was to evaluate the incidence of back pain and the frequency of medical treatment of these ailments by way of pharmaceutics or by rehabilitation, and to show the relationship of these symptoms with the degree of practiced recreational physical activity among a group of students of the Medical University of Lublin coming from rural areas or urban areas.

\section{MATERIAL AND METHODS}

The study involved 301 students (201 women and 100 men) of the second year of full-time study, aged from 19 to 27 years (median -20 years). The survey was undertaken at the turn of the year 2014/2015. The research tool was an anonymous survey that took into account, inter alia, data on the prevalence of back pain and its treatment, the number of visitation to specialised back-pain and/or orthopaedic clinics, and the degree of practiced recreational physical activity of the surveyed students coming from urban or rural areas.

The obtained survey results were subjected to statistical analysis with the use of Statistica 10.0 software. The chisquare $\left(X^{2}\right)$ test was applied to compare the mean students groups coming from urban and rural areas. In this regard, a probability (p) value less than 0.05 was considered statistically significant.

\section{RESULTS}

On the question concerning the use of medical care facilities such as the orthopaedic clinic, most students (more than $67.77 \%$ ) replied that they had not visit such. Regarding the specification of the respondents place of origin, the percentage distribution was similar: about $68.37 \%$ stating so came from the city, and about $66.28 \%$ of students came from rural areas (Figure 1).

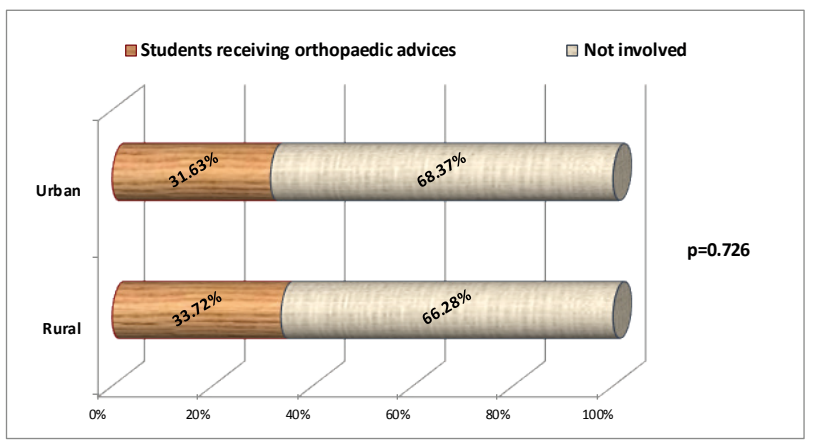

Figure 1. Have you ever sought the medical advice of the orthopedic/back pain clinic? (Chi^2 Pearson's: $0.123, \mathrm{df}=1$, $\mathrm{p}=0.726$ )

On the question of whether respondents have been treated due to back pain, the majority of students (83.39\% of respondents) answered that they had never been treated because of these ailments. Broken down, the figure for urban origin was $82.33 \%$; for rural origin - about $86.05 \%$ (Figure 2).

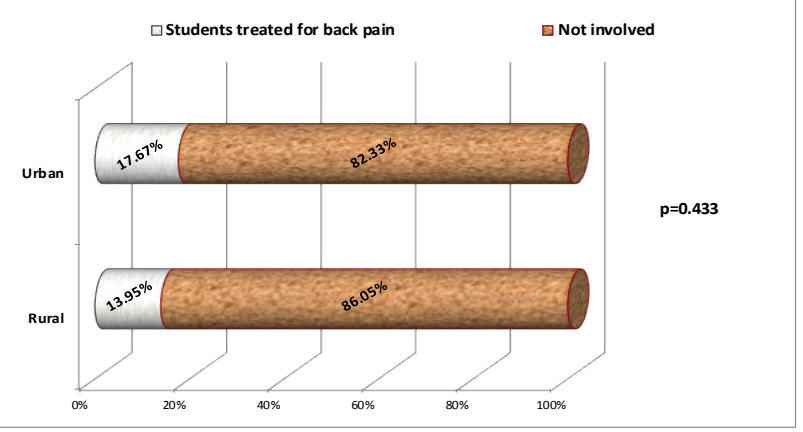

Figure 2. Have you ever been treated for back pain? (Chi^2 Pearson's: $0.613, \mathrm{df}=1, \mathrm{p}=0.433$ )

Among the respondents treated for back pain, approximately $8.3 \%$, were treated only once in their lifetime, or were treated a few times $-5.32 \%$, or many times - only about $3 \%$. Regarding origin, $8.84 \%$ of urban origin, and $6.97 \%$ of rural origin - were treated once. For having been treated several times, this figure is: urban origin - around $6 \%$, and rural origin - about $3.5 \%$. As to the degree of many times having gained treatment, about $2.79 \%$ were of urban origin, and $3.45 \%$ were of rural origin (Figure 3 ). 


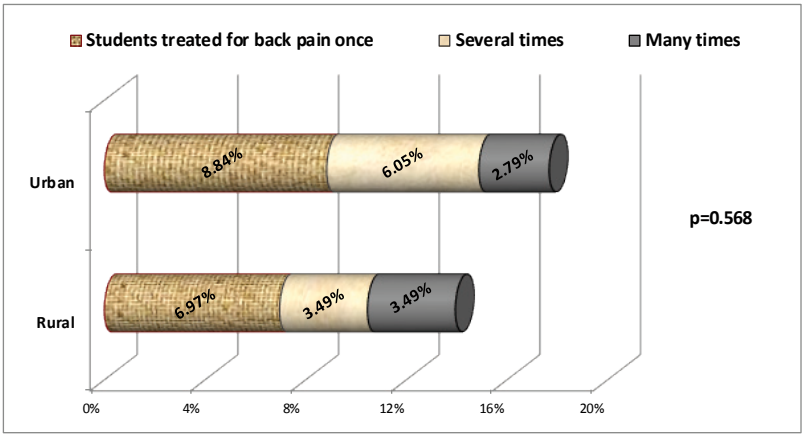

Figure 3. How many times in your life have you been treated for back pain? (Chi^2 Pearson's: $3.868, \mathrm{df}=5, \mathrm{p}=0.568)$

When asked about the pharmacological treatment of back pain, about $90 \%$ of the respondents answered that they had never been treated pharmacologically for these symptoms. In this regard, the percentage distribution among people from urban and rural areas was similar - about 90\% (Figure 4).

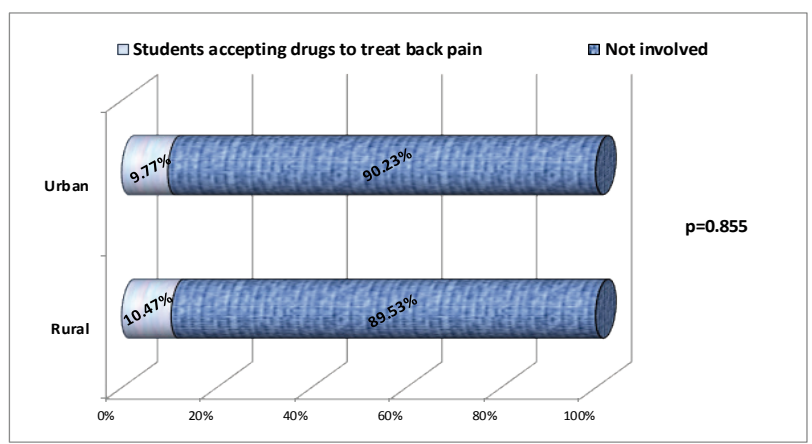

Figure 4. Have you ever had pharmacological treatment for back pain? (Chi^2 Pearson’s: $0.033, \mathrm{df}=1, \mathrm{p}=0.855)$

Among those who had treatment, approximately $4.65 \%$ were treated once in their lifetime, and only $5.32 \%$ had been treated so many times. Among the surveyed coming from urban areas, about $4.19 \%$ were treated many times, while among those from rural areas - this figure was $8.14 \%$ (Figure 5).

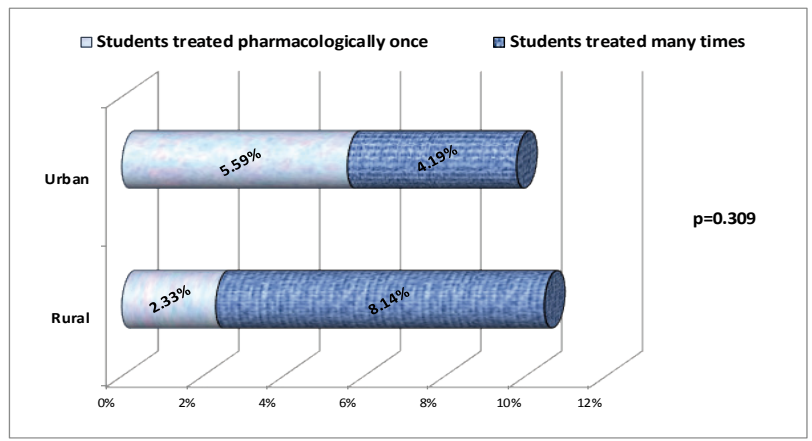

Figure 5. How many times have you undergone pharmacological treatment of back pain? (Chi^2 Pearson's: $3.591, \mathrm{df}=3, \mathrm{p}=0.309$ )

The majority of respondents, approximately $71 \%$, had never undergone physical therapy to treat chronic back pain. Regarding this figure, $68.84 \%$ of those from an urban origin, and $75.58 \%$ of those from rural areas, stated so (Figure 6).

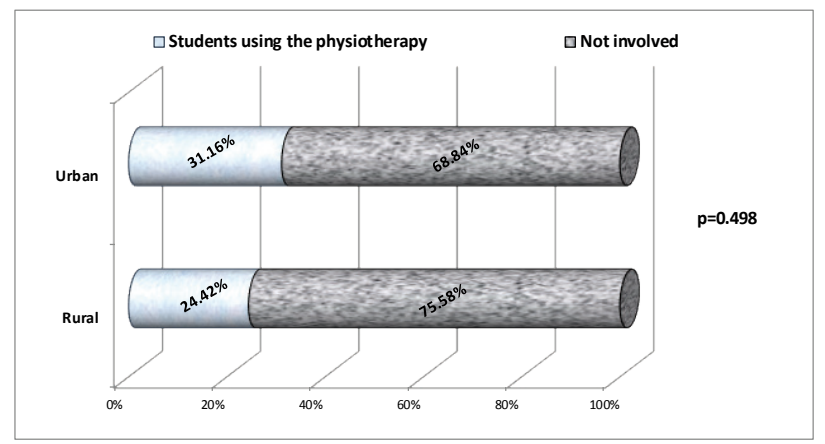

Figure 6. Have you ever undergone physiotherapy? (Chi^2 Pearson's: $3.371, \mathrm{df}=4, \mathrm{p}=0.498$ )

To establish the relationship between the incidence of back pain and degree of practiced physical activity at school, respondents were also asked about their participation in proffered physical recreation activities. A majority of students, about $90 \%$, stated that they were actively participating in physical recreation. Broken down, the figure was: urban origin $-88.84 \%$; rural origin $-90.70 \%$ (Figure 7 ).

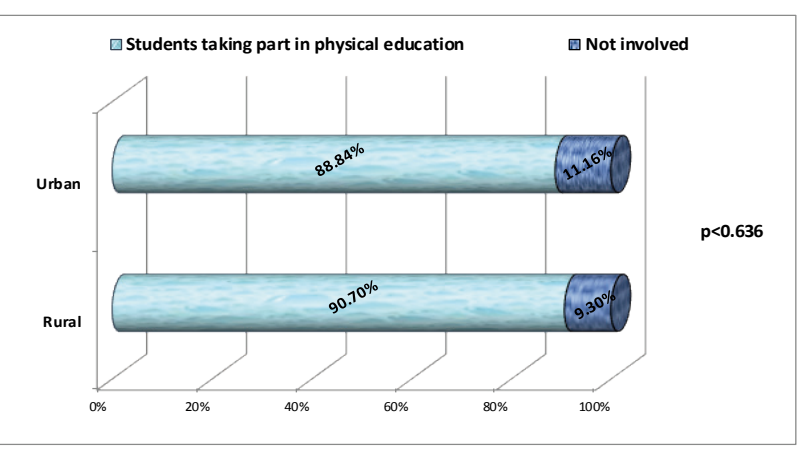

Figure 7. Do you actively participate in physical activities at school? $\left(\mathrm{Chi}^{\wedge} \wedge 2\right.$ Pearson’s: $\left.0.224, \mathrm{df}=1, \mathrm{p}<0.636\right)$

Also, most students, when asked about participating in sport, replied in the affirmative - approximately $81 \%$ of all surveyed actively spent free time playing some sort of sport. In the context of origin, this figure was: urban origin $85.12 \%$ of all students surveyed, and, rural origin - approximately $70.93 \%$ of all students (Figure 8 ). Of note: $20 \%$ of the surveyed students did not practice any sport.

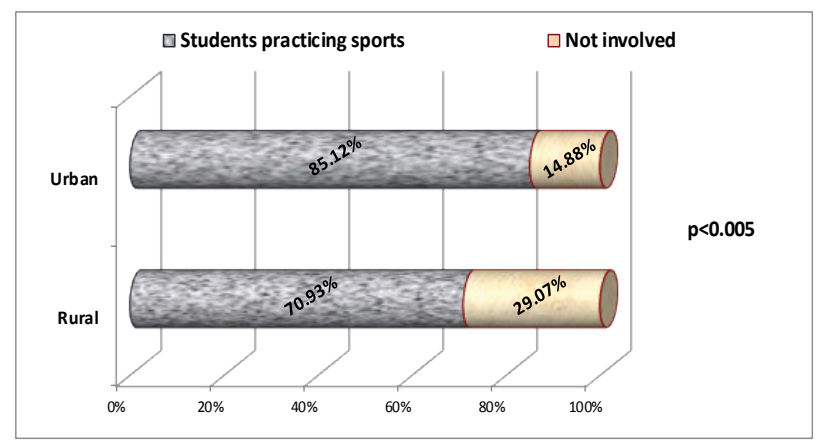

Figure 8. Do you practice a sport? $\left(\mathrm{Chi}^{\wedge}{ }^{2}\right.$ Pearson’s: $8.053, \mathrm{df}=1$, $\mathrm{p}<0.005)$

Among the sports participated in, more than $41 \%$ of all surveyed students played a variety of sports. Regarding this figure and considering origin, the survey results were: urban $-44.68 \%$; rural $-34.89 \%$. The sports popularly played were 
team sports such as volleyball, basketball, football and handball (13.61\%). Of this figure, it is notable that $15.11 \%$ of those playing such sports were of rural origin. Among the individually cultivated (sole) sport disciplines participated in, those surveyed stated that they enjoyed swimming and running. Less commonly cultivated, but also mentioned, were biking and dancing. Of this figure, it is notable that $16.75 \%$ of those playing a sole sport discipline were of urban origin (Figure 9).

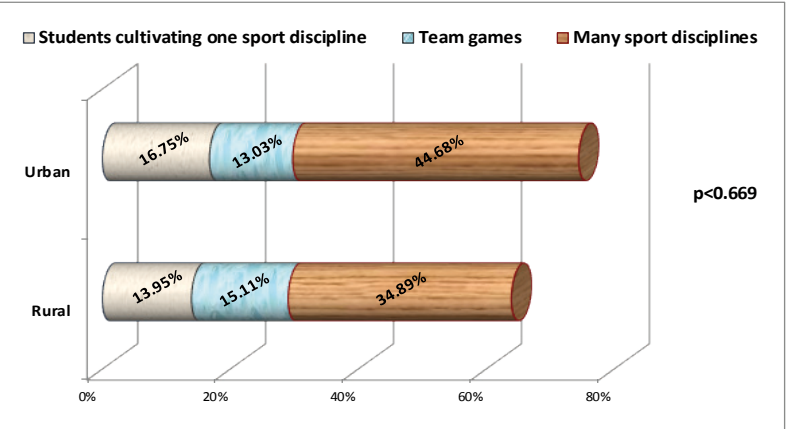

Figure 9. What kind of sport do you play? (Chi^ 2 Pearson’s: $30.849, \mathrm{df}=35, \mathrm{p}<0.669$ )

\section{DISCUSSION}

Regarding back pain, researchers have analyze, among other issues, the frequency of occurrence, the reasons for this phenomenon having come about, the types of the treatment applied and their efficacy. In such work, the observed trend is to see greater reportage of back pain in children and adolescents. This is a very worrying phenomenon because back pain greatly affects the quality and comfort of life, both in the present and in the future $[2,14,15,16]$.

In our study of students of the Medical University of Lublin, we have discovered that approximately $16 \%$ of all surveyed had encountered incidences of back pain. When compared with the results gained by Drozda and Lewandowski, the incidence of back pain within the studied medical students was much lower than that in secondary school students (15-20 years) who had come from Poznań. What is more, in Drozda and Lewandowski's work, back pain was seen to have occurred in approximately $79.9 \%$ of all surveyed, while no problems were reported by approximately $17 \%$ of the respondents [3]. However, according to the results of the Health Behavior in School-aged Children (HBSC) study of 2010 that was carried out among young people 11-18 years old, and which asked about back pain, a prevalence was noted with increasing age. The obtained figure in boys aged 17-18 years was $-11.8 \%$. Regarding the degree of back pain experienced by girls, the obtained figure in the aged 17-18 years category was $-21.5 \%$ [12]. In contrast, according to another study of Drozda K. et al. of young, middle and high school students aged 13-20 years living in Poznan, $67 \%$ of the surveyed said they had experienced back pain, and 49\% stated that they had recurrent problems. Moreover, according to those surveyed, such pain was experienced most frequently in the lumbar-sacral area (in more than $70 \%$ of respondents) and occurred most often in individuals between 14 and 16 years of age [4] .

The increasing prevalence of these disorders is associated with the increasing body weight and Body Mass Index (BMI) that have been observed in children in the last decade, as well as with their noted deterioration in physical fitness. In the European Union countries, overweight and obesity affects one in four teenage schoolchildren. In Poland, in 2009 , such states of being were found in $16.4 \%$ of all children aged 6-19 years (18.7\% of all boys and $14.3 \%$ of all girls). The incidences of overweight and obesity among children and adolescents is seen to be increasing by about $2-3 \%$ per decade [6]. In contrast, in their examination of physical fitness in children aged 6-19 years, Wolański et al. noted that over the period of 1999-2009, the physical fitness of both boys and girls had significantly deteriorated [21]. However, Woynarowska and Mazur, who carried out a similar survey of high school students, noticed an increase in physical activity over the years 1990-2010, but concluded that their level of activity was still unsatisfactory [22]. Woynarowska and Mazur, put forward a recommended level of basic physical activity that is of at least 60 minutes duration a day, 7 days a week. Approximately $80 \%$ of all boys surveyed aged $17-18$ years and $95.8 \%$ of girls surveyed in the same age range did not meet even this [22].

The opportunity to take part in physical fitness activities is proffered in primary, lower and upper secondary schools, as well as in places of higher learning, through physical education classes. At the medical field, such classes are, according to our research, attended by only nine tenth of all those surveyed. Yet, of note, according to Smolen and Gozdowicz, by way of their study of students of the State Higher Vocational School in Sanok, only $79.7 \%$ of the surveyed students regularly attended physical education classes [17]. It seems, therefore, that with age, absenteeism increases for physical education classes. This, of course, depends on the type of school, the youth origin and gender.

One of the causes of disorders of the musculoskeletal system is the rapid growth and development of the posture. According to various authors, the frequency of the occurrence of such disorders is $10-80 \%$ of the total population. Such large differences in estimation stem from a lack of standardized diagnostic criteria, as well as unavoidable variation in the course of individual posturogenesis. It can be assumed then, that around $10-15 \%$ of all children and adolescents are afflicted with serious disorders of the musculoskeletal system. The most common of these are: scoliosis (lateral curvature of the spine), juvenile kyphosis, Scheuermana disease and static distortion of the limbs [23]. In our survey, we asked whether the respondent had undergone treatment for clinical posture correction in childhood. Among the students surveyed, about one third of the total had undergone correction therapy. Appropriate prevention practices must be enacted to minimize the consequences of bad posture. Such practices include a high degree of physical activity, ergonomically correct bedding, home and school furniture, as well as good foot-ware [23]. Prophylaxis includes daily care to maintain correct body posture, elimination of factors that endanger correct posture, the provision of exercise to enable comprehensive and harmonious 
development of the physical body, as well as regular health check-ups [5]. It seems that medical students understand the need for physical activity. However, too little comply with the recommendations. According to our research, about one fifth of the surveyed students do not undertake some sort of sporting activity. Most cultivated disciplines were team games such as volleyball, basketball, handball and football, running, swimming. Sochocka and Wojtyłko obtained different results in their study of a mixed group of medical and non-medical students. In their work, approximately $79.5 \%$ of all students identified themselves as being physically active individuals. Moreover, forms of physical activity undertaken included cycling $-40.5 \%$ of all students, team sports $27.1 \%$, walking their dogs $-27.1 \%$, group classes (aerobics, zumba, salsa) $-21.2 \%$ and swimming $-20.8 \%$ [18].

\section{CONCLUSIONS}

1. Some medical students experience back-ache, however, the frequency is less than in other age groups, Indeed, $83.39 \%$ of all surveyed reported no back pain.

2. Students of medical fields exhibit a satisfactory degree of physical activity, although approximately $20 \%$ of all surveyed are not practicing any sport. In this respect, $29.07 \%$ of all those of rural origin practice no sports at all.

\section{REFERENCES}

1. Bergier et al.: Physical activity of Polish adolescents and young adults according to IPAQ: a population based study. Annals of Agricultural and Environmental Medicine, Vol 19, No1, 109-115, 2012.

2. Dobosiewicz K.: Niespecyficzne bóle kręgosłupa u dzieci i młodzieży - uwarunkowania biomechaniczne, neurofizjologiczne oraz psychospołeczne. Neurologia dziecięca, 15, 30, 51-57, 2006.

3. Drozda K., Lewandowski J.: Epidemiologia bólów kręgosłupa wśród młodzieży szkół średnich Poznania. Fizjoterapia Polska. 11, 31-40, 2011

4. Drozda K., Lewandowski J., Górki P.: Bóle kręgosłupa u młodzieży szkół gimnazjalnych i ponadgimnazjalnych zamieszkałej w środowisku miejskim w Polsce, na przykładzie Poznania. Ortopedia Traumatologia Rehabilitacja, 5, 2011.

5. Górecki A. et al.: Profilaktyka wad postawy u dzieci i młodzieży w środowisku nauczania i wychowania - rekomendacje, Warszawa, 2009.

6. Grajda A. et al.: Regional differences in prevalence of overweight, obesity and underweight among Polish children and adolescents. Medycyna Wieku Rozwojowego, 15, 3, 258-265, 2011.
7. Hamberg-van Reenen H. et al.: Physical capacity in relation to low back, neck, or shoulder pain in a working population, Occup Environ Med, 63:371-377, 2006; doi: 10.1136/oem.2006.026914

8. Hardie R. et al.: The Effects of Bag Style on Muscle Activity of the Trapezius, Erector Spinae and Latissimus Dorsi During Walking, in Female University Students. Journal of Human Kinetics 45: 39-47, 2015; doi: 10.1515/hukin-2015-0005

9. Kim D. et al.: Effect of an exercise program for posture correction on musculoskeletal pain J. Phys. Ther. Sci., 27: 1791-1794, 2015.

10. Latalski M. et al.: Risk factors of postural defects in children at school age. Annals of Agricultural and Environmental Medicine, 20, 583-587, 2013.

11. Marley J. et al.: A systematic review of interventions aimed at increasing physical activity in adults with chronic musculoskeletal pain-protocol. Systematic Reviews, 3:106, 2014.

12. Mazur J., Małkowska-Szkutnik A.: Wyniki badań HBSC 2010. Raport techniczny. Instytut Matki I Dziecka, Warszawa, 2011.

13. Miñana-Signes V., Monfort-Pan ego M.: Knowledge on health and back care education related to physical activity and exercise in adolescents. Eur Spine J, 2015; doi: 10.1007/s00586-015-3953-7

14. Paprocka J. et al.: Zespoły bólowe kręgosłupa u dzieci. Wiadomości lekarskie LXI, 7-9, 183-189, 2008.

15. Pawłowska P. et al.: Dolegliwości bólowe kręgosłupa u dzieci - ocena związku z hipermobilnością stawową i elastycznością wybranych mięśni kompleksu lędźwiowo-miedniczno-biodrowego. Nowa pediatria, 2, 39-43, 2013.

16. Sienkiewicz D. et al.: Bóle kręgosłupa w wieku dziecięcym - kolejne wyzwanie dla współczesnej medycyny. Neurologia dziecięca, 20, 41, 129-133, 2011.

17. Smoleń E., Gozdowicz L.: Ocena aktywności fizycznej młodzieży akademickiej. Pielęgniarstwo XXI wieku, 4, 41, 2012.

18. Sochocka L., Wojtyłko A.: Aktywność fizyczna studentów studiów stacjonarnych kierunków medycznych i niemedycznych. Environmental medicine, 15, 2, 2013.

19. Trevelyan F.C., Legg S.J.: Back pain in school children - Where to from here? Applied Ergonomics, 37:45-54, 2006; doi:10.1016/j. apergo.2004.02.008

20. Wedderkopp N. et al.: High-level physical activity in childhood seems to protect against low back pain in early adolescence The Spine Journal, 9:134-141, 2009; doi:10.1016/j.spinee.2008.02.003

21. Wolański N., Dobosz J.: Tendencje przemian motoryczności człowieka (międzydekadowe zmiany efektywności). In: Uwarunkowanie rozwoju dzieci i młodzieży wiejskiej, Biała Podlaska; p: 8-44, 2012.

22. Woynarowska B., Mazur J.: Tendencja zmian zachowań zdrowotnych i wybranych wskaźników zdrowia młodzieży szkolnej w latach 19902010. Instytut Matki i Dziecka, Wydział Pedagogiczny Uniwersytetu Warszawskiego, Warszawa, 2012.

23. Woynarowska B., Oblacińska A.: Stan zdrowia dzieci i młodzieży $w$ Polsce. Najważniejsze problemy zdrowotne. Studia BAS, 2, 38, 41-64, 2014; www.bas.sejm.gov.pl

24. Woynarowska B., Mazur J., Oblacińska A.: Uczestnictwo uczniów w lekcjach wychowania fizycznego w szkołach w Polsce. Hygeia Public Health, 50(1): 183-190, 2015. 